\title{
Faktor-Faktor Yang Mempengaruhi Nilai Perusahaan Pada Perusahaan Manufaktur Sektor Aneka Industri
}

\author{
Brittany Callista Hamidjaja dan Khairina Natsir \\ Fakultas Ekonomi Universitas Tarumanagara Jakarta \\ Email: brittanycallista97@gmail.com
}

\begin{abstract}
The purpose of this study is to find out the effects of profitability, capital structure, and firm size on firm's value in various industrial sector in manufacturing companies listed on the Indonesian Stock Exchange. This research uses panel data regression analysis, using 17 companies various industrial sector in manufacturing companies that have been selected through census method of a total 17 companies over five years and resulting 85 samples data. The data used are secondary data which includes financial statements. Processing carried out in this study uses Eviews version 9 software. The results of this study indicate that profitability and leverage have a significant influence on firm's value, but for firm size does not significantly influence on firm's value.
\end{abstract}

Key word: firm value, profitability, leverage, firm size.

Abstrak: Tujuan dari penelitian ini adalah untuk melihat pengaruh dari profitabilitas, leverage, dan ukuran perusahaan terhadap nilai perusahaan pada perusahaan manufaktur sektor aneka industri yang terdaftar di Bursa Efek Indonesia. Penelitian ini menggunakan alat analisis regresi data panel, dengan menggunakan 17 perusahaan manufaktur sektor aneka industri yang sudah diseleksi melalui metode sensus selama lima tahun dan menghasilkan 85 sampel data perusahaan. Data yang digunakan adalah data sekunder yang meliputi laporan keuangan. Pengolahan yang dilakukan dalam penelitian ini menggunakan software Eviews versi 9. Hasil dari penelitian ini menunjukkan bahwa profitabilitas dan leverage berpengaruh secara signifikan terhadap nilai perusahaan. namun, ukuran perusahaan tidak berpengaruh secara signifikan terhadap nilai perusahaan.

Kata kunci: nilai perusahaan, profitabilitas, leverage, dan ukuran perusahaan. 


\section{LATAR BELAKANG}

Pada era globalisasi ini, para investor lebih kritis dalam menentukan perusahaan yang akan mereka jadikan tempat untuk berinvestasi. Para analis juga akan semakin kritis untuk menilai perusahaan bahwa return yang ditawarkan menjanjikan atau tidak bagi investor yang akan berinvestasi. Hal ini sesuai dengan pandangan (Salempang, Sondakh, \& Pusung, 2016) yang menurutnya calon investor dalam mengambil suatu keputusan dalam berinvestasi memerlukan analisis yang tentunya akurat. Dari sudut pandang lain, banyak sekali perusahaan yang saling bersaing untuk dapat menarik investor ke perusahaannya demi kelancaran dan kelanjutan jalannya suatu perusahaan. Perusahaan harus dapat menarik bagi mata investor agar investor setuju untuk menanamkan modalnya di perusahaan tersebut.

Penelitian ini menggunakan sektor aneka industri dengan alasan pertama, karena sektor ini merupakan sektor yang memproduksi atau menjual produk yang menjadi kebutuhan masyarakat banyak seperti menjual kendaraan mobil dan motor, spare part kendaraan, sepatu, dan lain-lainnya. Selain itu, alasan dibalik memilih sektor ini karena sektor aneka industri mengalami penurunan. Harga saham sektor aneka industri tentunya fluktuatif. Pada awal tahun 2019, sektor aneka industri mengalami kenaikan hanya sebesar 0,85\% (www.kontan.co.id). Kenaikan sektor ini merupakan kenaikan paling terendah dibandingkan sektor lain. Namun, pada bulan April 2019 sektor aneka industri mengalami pelemahan sebesar $1,56 \%$ yang mana penurunannya paling besar jika dibandingkan dengan sektor lainnya. Dengan adanya penurunan nilai perusahaan maka maka penting untuk mengetahui bagaimana pengaruh dari faktor profitabilitas, leverage, dan ukuran perusahaan yang dimiliki perusahaan terhadap nilai perusahaan sehingga ke depannya perusahaan dapat memperbaiki nilai perusahaannya agar meningkat.

Hasil yang menunjukkan bahwa profitabilitas berpengaruh positif dan signifikan terhadap nilai perusahaan sesuai dengan penelitian dari (Kalbuana dkk., 2017) dan (Ayu \& Suarjaya, 2017). Namun, di sisi lain terdapat hasil yang bertentangan yaitu dari penelitian (Salempang dkk., 2016) dan (Oktrima, 2017) yang menunjukkan bahwa profitabilitas berpengaruh secara tidak signifikan terhadap nilai perusahaan. Selanjutnya, penelitian dari (Aggarwal \& Padhan, 2017) menunjukkan pengaruh yang signifikan antara leverage dengan nilai perusahaan. Namun, sebaliknya berdasarkan hasil penelitian (Kalbuana dkk., 2017) menunjukkan bahwa leverage berpengaruh secara tidak signifikan terhadap nilai perusahaan. Berdasarkan penelitian dari (Kalbuana dkk., 2017) dan (Aggarwal \& Padhan, 2017) menyatakan bahwa adanya pengaruh yang signifikan antara ukuran perusahaan dengan nilai perusahaan. Sebaliknya, hasil dari penelitian (Manoppo \& Arie, 2016), (Lumoly, Urni, \& Untu, 2018), dan (Winarto, 2015) menunjukkan bahwa ukuran perusahaan berpengaruh secara tidak signifikan terhadap nilai perusahaan.

Hasil dari penelitian sebelumnya masih sering terjadi hasil yang tidak konsisten antara pengaruh tidaknya antara variabel bebas yaitu profitabilitas, leverage, dan ukuran perusahaan terhadap nilai perusahaan. Hal ini menunjukkan diperlukannya penelitian lebih lanjut pengaruh akan variabel profitabilitas, leverage, dan ukuran perusahaan tersebut terhadap nilai perusahaan

Bagi perusahaan-perusahaan yang sudah go public, tentunya nilai suatu perusahaan akan tercermin dari nilai pasar harga sahamnya. Semakin tinggi harga saham suatu perusahaan semakin tinggi pula nilai perusahaan tersebut. Tujuan memaksimumkan nilai perusahaan ini digunakan sebagai pengukur keberhasilan perusahaan karena dengan 
meningkatnya nilai perusahaan berarti meningkat pula kemakmuran pemilik perusahaan atau pemegang saham perusahaan (Harjito \& Martono, 2014). Banyak sekali faktor-faktor yang dapat mempengaruhi naik turunnya nilai saham perusahaan. Semakin tinggi atau semakin baik nilai perusahaan akan semakin meningkatkan ketertarikan investor untuk menanamkan modalnya, sehingga perusahaan dapat bertumbuh lebih besar atau dapat melakukan ekspansi dengan modal yang ditanamkan investor. Oleh karena itu, maka akan sangat penting bagi perusahaan untuk mengetahui berbagai faktor-faktor yang dapat mempengaruhi nilai perusahaan. Faktor-faktor tersebut misalnya: profitabilitas, leverage, dan ukuran perusahaan.

\section{KAJIAN TEORI}

Trade Off Theory. Trade-off theory menunjukkan adanya keseimbangan antara manfaat yang diperoleh dari menggunakan dana oleh hutang dengan kemungkinan masalah yang dapat timbul dari potensi kebangkrutan (Brigham E.F., 2011). Teori Trade off tentang struktur modal ini adalah sebuah gagasan perusahaan untuk memilih antara berapa banyak jumlah akan pembiayaan dengan hutang dan berapa banyak jumlah ekuitas yang digunakan supaya tercipta keseimbangan antara biaya dan manfaat. (https://en.wikipedia.org).

Signalling Theory. Menurut Brigham \& Houston (2014) Signalling Theory menjelaskan bahwa suatu perilaku manajemen perusahaan dalam memberikan petunjuk untuk investor terkait pandangan manajemen pada prospek perusahaan untuk masa mendatang. Sinyal ini memberikan informasi hal-hal yang sudah dilakukan manajemen untuk merealisasikan keinginan-keinginan pemiliknya. Tentunya informasi yang diterbitkan oleh perusahaan penting adanya, karena informasi tersebut berpengaruh terhadap keputusan investasi oleh pihak yang ada di luar perusahaan.

Menurut Sartono (2010:487), nilai perusahaan adalah nilai jual sebuah perusahaan sebagai suatu bisnis yang sedang beroperasi. Nilai perusahaan sangat penting karena dengan nilai perusahaan yang tinggi akan diikuti oleh tingginya kemakmuran pemegang saham, Semakin tinggi harga saham semakin tinggi pula nilai perusahaan. Keinginan pemilik perusahaan tentunya untuk memliki nilai perusahaan yang tinggi, hal ini dikarenakan dengan nilai perusahaan yang tinggi menunjukan bahwa para pemegang sahamnya memiliki kemakmuran yang tinggi juga. Nilai perusahaan yang tinggi memberikan gambaran bahwa kinerja perusahaan baik adanya sehingga dapat meyakinkan para investor bahwa perusahaan mempunyai prospek yang baik di masa yang akan datang (Ayu \& Suarjaya, 2017).

Profitabilitas memiliki definisi yang bermacam-macam dari para ahli, profitabilitas ini menunjukkan besarnya kemampuan suatu perusahaan untuk menghasilkan keuntungan bagi investor dimana kemampuan perusahaan tersebut akan menentukan seberapa baiknya perusahaan di mata para investor jika dilihat dari segi keuangannya (Ayu \& Suarjaya, 2017). Jika dilihat dari sudut pandang lain menurut Syahyunan (2015) profitabilitas adalah rasio yang dapat digunakan untuk mengetahui seberapa besar kemampuan perusahaan dalam menghasilkan laba atau seberapa efektif pengelolaan perusahaan oleh manajemen.

Leverage. merupakan rasio yang digunakan untuk mengukur sejauh mana aktiva perusahaan dibiayai dengan utang (Kasmir, 2014), artinya berapa besar beban utang yang ditanggung perusahaan dibandingkan dengan aktivanya. 
Ukuran Perusahaan atau Firm Size merupakan besarnya kekayaan yang dimiliki oleh suatu perusahaan. Semakin besar perusahaan maka semakin dikenal oleh masyarakat yang artinya semakin mudah untuk mendapatkan informasi yang akan meningkatkan nilai perusahaan. Ukuran perusahaan ini pada umumnya berpengaruh terhadap keputusan investor untuk berinvestasi (Rahmawati dkk., 2015). Menurut Riyanto (2001:299) Ukuran perusahaan (Firm Size) merupakan menggambarkan besar kecilnya suatu perusahaan yang ditunjukan pada total aktiva, jumlah penjualan, rata-rata penjualan dan total aktiva

Kerangka pemikiran yang digunakan dalam penelitian ini dapat dilihat pada gambar berikut:

Gambar 1. Kerangka Pemikiran

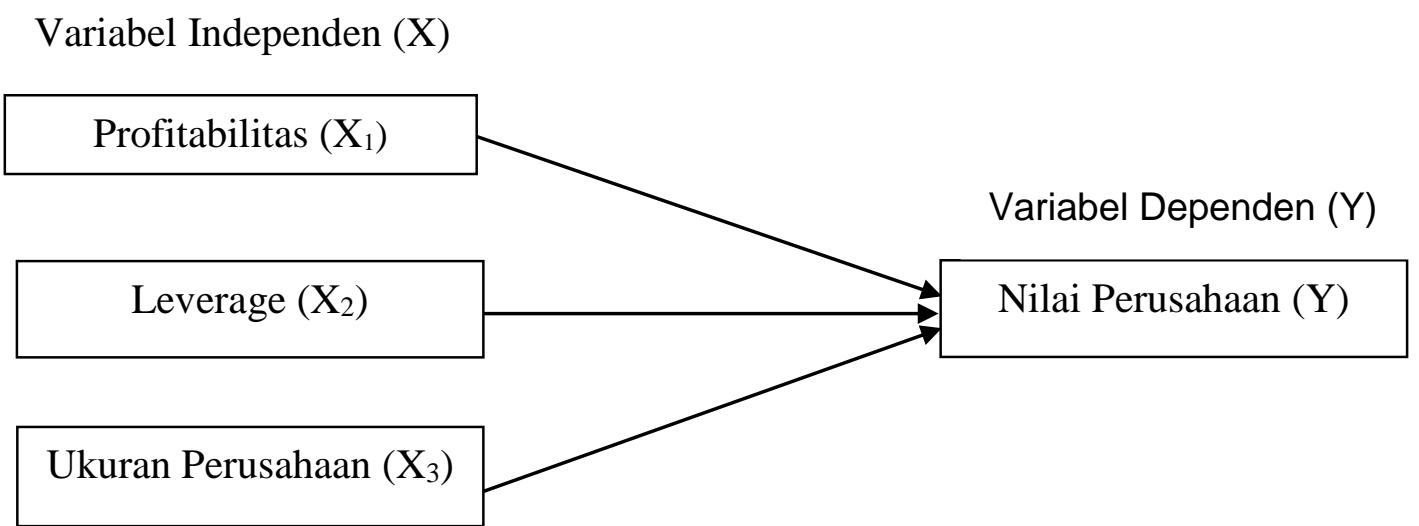

Hipotesis dalam penelitian ini adalah sebagai berikut:

H1: Profitabilitas berpengaruh positif dan signifikan terhadap Nilai Perusahaan.

H2: Leverage berpengaruh negatif dan signifikan terhadap Nilai Perusahaan.

H3: Ukuran Perusahaan berpengaruh positif dan signifikan terhadap Nilai Perusahaan.

\section{METODOLOGI}

Subjek yang dipakai dalam penelitian ini adalah perusahaan manufaktur sektor aneka industri yang terdaftar secara berturut-turut pada Bursa Efek Indonesia (BEI) tahun 20132017. Populasi dalam penelitian ini adalah perusahaan manufaktur sektor aneka industri yang memperoleh keuntungan dan terdaftar di BEI periode 2013-2017. Teknik pemilihan sampel yang digunakan adalah sensus. Banyaknya sampel yang digunakan dalam penelitian ini adalah 17 sampel.

Objek penelitian ini adalah variabel yang digunakan yang terdiri dari satu variabel dependen dan tiga variabel independen. Variabel dependen yang digunakan dalam penelitian ini adalah nilai perusahaan, sedangkan variabel independen yang digunakan dalam penelitian ini adalah profitabilitas, leverage, dan ukuran perusahaan.

Variabel dependen yang digunakan dalam penelititan ini adalah Price Book Value (PBV) yang dihitung dengan model perhitungan sebagai berikut : 


$$
\begin{gathered}
P B V=\frac{\text { Market Price per Share }}{\text { Book Value per Share }} \\
\text { Book Value per Share }=\frac{\text { Total Equity }}{\text { Outstanding Share }}
\end{gathered}
$$

Profitabilitas adalah rasio yang digunakan untuk mengukur kemampuan perusahaan dalam menghasilkan labanya. Proksi yang digunakan untuk mengukur profitabilitasnya adalah return on assets (ROA). Menurut Hery (2017:314) rumus ROA adalah sebagai berikut:

$$
\text { Return On Assets }=\frac{\text { Net Income }}{\text { Total Assets }}
$$

Leverage merupakan rasio yang digunakan untuk mengukur sejauh mana aktiva perusahaan dibiayai dengan utang (Kasmir, 2014), artinya berapa besar beban utang yang ditanggung perusahaan dibandingkan dengan aktivanya. Dalam melakukan penilaian akan leverage digunakan rasio Total Debt to Total Equity Ratio (DER). Rumus untuk menghitung DER adalah (Manoppo \& Arie, 2016) :

$$
\text { Debt to Equity Ratio }=\frac{\text { Total Liabilities }}{\text { Total Equity }}
$$

Ukuran perusahaan merupakan suatu nilai yang menggambarkan besar kecilnya suatu perusahaan. Untuk mengukur besarnya ukuran perusahan dapat digunakan logaritma natural dari total aktiva perusahaan. Rumus yang dapat digunakan untuk mengukur besarnya ukuran perusahaan ini adalah (Kalbuana dkk., 2017) :

$$
\text { Firm Size }=\text { Ln Total Assets }
$$

Uji statistik yang digunakan dalam penelitian ini antara lain uji statistik deskriptif, uji multikolinearitas, uji likehood, uji hausman, uji lagrange multiplier, uji signifikansi parameter individu (uji t), dan uji koefisien determinasi $\left(\mathrm{R}^{2}\right)$.

\section{HASIL ANALISIS DATA}

Statistik deskriptif mampu untuk memberi gambaran tentang suatu data yang dapat terlihat dari nilai rata-rata, nilai tengah, standar deviasi, nilai maksimum, dan nilai minimum yang dapat dihasilkan oleh masing-masing variabel yaitu profitabilitas, leverage, dan ukuran perusahaan. Pada jumlah observasi sebesar 85 data, nilai rata-rata (mean) untuk nilai perusahaan yang diukur dengan Price Book Value (PBV) adalah sebesar 1,041887. Nilai tengah (median) dapat ditunjukkan oleh perusahaan Trisula International Tbk pada tahun 2017 yaitu sebesar 0,905200. Sedangkan, nilai maksimum dapat ditunjukkan oleh perusahaan Selamat Sempurna Tbk pada tahun 2017 sebesar 3,953200 dan nilai minimum dapat ditunjukkan oleh perusahaan Nusantara Inti Corpora Tbk pada tahun 2017 sebesar 0,070100. Untuk standar deviasi yang dapat ditunjukkan adalah sebesar 0,857736. 
Profitabilitas memiliki nilai rata-rata (mean) yaitu sebesar 0,055915. Nilai tengah (median) dapat ditunjukkan oleh perusahaan Nippres Tbk pada tahun 2013 yaitu sebesar 0,042400 . Sedangkan, untuk nilai maksimum dapat ditunjukkan oleh perusahaan Selamat Sempurna Tbk pada tahun 2014 yaitu sebesar 0,240300 dan untuk nilai minimum dapat ditunjukkan oleh perusahaan Indospring Tbk pada tahun 2015 yaitu sebesar 0,0008. Untuk standar deviasinya adalah sebesar 0,055058 . Nilai tengah atau median menunjukan nilai sebesar 0,061500. Nilai maksimum sebesar 0,526700 yang merupakan nilai yang dimiliki oleh perusahaan Multi Bintang Indonesia Tbk untuk tahun 2017, dan nilai minimum sebesar 0,000200 yang merupakan nilai yang dimiliki oleh perusahaan Voksel Electric Tbk untuk tahun 2015. Untuk standar deviasi yang ada menunjukkan nilai 0,081980.

Leverage memiliki nilai rata-rata (mean) adalah sebesar 1,051001. Nilai tengah (median) dapat ditunjukkan oleh perusahaan Pan Brothers Tbk pada tahun 2014 yaitu sebesar 0,791000. Sedangkan, nilai maksimum dapat ditunjukkan oleh perusahaan Jembo Cable Company Tbk pada tahun 2013 yaitu sebesar 7,396400 dan nilai minimum dapat ditunjukkan oleh Indospring Tbk pada tahun 2017 sebesar 0,135100. Untuk standar deviasinya adalah sebesar 1.035034 .

Ukuran perusahaan memiliki nilai rata-rata (mean) sebesar 28,53163. Nilai median dapat ditunjukkan dengan perusahaan Selamat Sempurna Tbk pada tahun 2014 yaitu sebesar 28,19030. Sedangkan, nilai maksimum dapat ditunjukkan oleh perusahaan Astra International Tbk pada tahun 2017 yaitu sebesar 33,32020 dan nilai minimum dapat ditunjukkan oleh perusahaan Nusantara Inti Corpora Tbk pada tahun 2017 yaitu sebesar 26,77860. Untuk standar deviasinya adalah 1,502142.

Uji multikolinearitas menunjukkan hasil korelasi antara variabel independen profitabilitas (ROA) dengan leverage (DER) adalah -0,282946 karena nilainya kurang dari 0,8 maka tidak terdapat multikolinearitas. Selain itu, korelasi antara variabel independen profitabilitas (ROA) dan ukuran perusahaan (Firm Size) adalah sebesar 0,091017, besar nilainya kurang dari 0,8 sehingga tidak terdapat miultikolinearitas. Yang terakhir adalah korelasi antara variabel independen leverage (DER) dan ukuran perusahaan (Firm Size) yang nilainya sebesar $-0,059690$, karena nilainya kurang dari 0,8 maka tidak terdapat multikolinearitas. Tidak terdapatnya multikolinearitas pada ketiga variabel menandakan tidak adanya korelasi atau hubungan satu sama lain.

Uji Chow/ Uji Likehood digunakan untuk melakukan pemilihan model antara common effect model atau fixed effect model sebagai model yang tepat digunakan untuk melakukan pengolahan data. Hasil uji chow menunjukkan bahwa nilai probabilitas cross section $\mathrm{F}$ sebesar $0,0000<0,05(\alpha=5 \%)$ sehingga model sebagai hasil yang lebih tepat untuk digunakan dalam pengolahan data adalah model fixed effect. Uji hausman dilakukan untuk menguji kembali apakah fixed effect model atau random effect model yang cocok untuk digunakan. Hasil uji hausman di atas menunjukkan nilai probabilitas cross section random adalah sebesar 0,2563 . Nilai tersebut lebih besar dari tingkat signifikansi $0,05(\alpha=$ $5 \%$ ) sehingga menunjukkan bahwa model random effect yang digunakan sebagai hasil pengolahan data yang digunakan. Selanjutnya, uji lagrange multiplier untuk menentukan pemilihan model yang tepat antara common effect atau random effect dilihat dari nilai yang dihasilkan dari cross section Breusch Pagan. Hasilnya menunjukkan nilai cross section Breusch Pagan adalah sebesar 0,0000. Nilai tersebut lebih kecil dari 0,05 sehingga model yang lebih tepat untuk digunakan adalah model random effect. Pada akhirnya, estimasi model data panel yang digunakan adalah model random effect sebagai pengolahan data yang tepat. 
Tabel 1. Hasil Pengolahan data dengan Eviews 9.0

\begin{tabular}{|c|c|c|c|c|}
\hline Variable & \multicolumn{2}{|c|}{ CoefficientStd. Error } & t-Statistic & Prob. \\
\hline ROA & 8.191553 & 1.668477 & 4.909598 & 0.0000 \\
\hline DER & 0.337275 & 0.080744 & 4.177090 & 0.0001 \\
\hline Firm Size & 0.140058 & 0.081041 & 1.728233 & 0.0878 \\
\hline \multirow[t]{3}{*}{$\mathrm{C}$} & -3.766708 & 2.322177 & -1.622059 & 0.1087 \\
\hline & \multirow{2}{*}{\multicolumn{2}{|c|}{ Effects Specification }} & & \\
\hline & & & S.D. & Rho \\
\hline \multirow{2}{*}{\multicolumn{3}{|c|}{$\begin{array}{l}\text { Cross-section random } \\
\text { Idiosyncratic random }\end{array}$}} & 0.477587 & 0.5292 \\
\hline & & & 0.450453 & 0.4708 \\
\hline & \multicolumn{4}{|c|}{ Weighted Statistics } \\
\hline R-squared & 0.314255 & Mean de & pendent var & 0.404925 \\
\hline Adjusted R-squared & 0.288857 & S.D. dep & endent var & 0.537605 \\
\hline S.E. of regression & 0.453358 & Sum squ & ared resid & 16.64824 \\
\hline F-statistic & 12.37324 & Durbin- & Vatson stat & 0.990248 \\
\hline \multirow[t]{2}{*}{ Prob(F-statistic) } & 0.000001 & & & \\
\hline & \multicolumn{3}{|c|}{ Unweighted Statistics } & \\
\hline R-squared & 0.446500 & \multirow{2}{*}{\multicolumn{2}{|c|}{$\begin{array}{l}\text { Mean dependent var } \\
\text { Durbin-Watson stat }\end{array}$}} & 1.041887 \\
\hline Sum squared resid & 34.20619 & & & 0.481956 \\
\hline
\end{tabular}

Berdasarkan hasil penelitian yang dilakukan, maka hasil analisis regresi dapat disimpulkan dalam persamaan model regresi yaitu:

$$
\mathrm{PBV}=-3.766708+8.191553 \mathrm{ROA}+0.337275 \mathrm{DER}+0.140058 \text { Firm Size }+\varepsilon
$$

Tabel diatas juga menunjukkan hasil uji t yang digunakan untuk mengetahui apakah terdapat pengaruh secara parsial dari variabel independen terhadap variabel dependen. Pengujian ini dilakukan dengan melihat tingkat signifikansinya. Variabel profitabilitas memiliki nilai signifikansi sebesar 0,0000 nilai ini lebih kecil dari tingkat signifikansinya yaitu $0,05(\alpha=5 \%)$ sehingga dapat disimpulkan bahwa $\mathrm{H}_{0}$ ditolak dan $\mathrm{H}_{1}$ diterima yang dapat diartikan adanya pengaruh signifikan antara variabel profitabilitas terhadap nilai perusahaan secara parsial atau individual dan memiliki arah koefisien regresi positif sebesar 8,191553 terhadap nilai perusahaan oleh karena itu hipotesis pertama $\left(\mathrm{H}_{1}\right)$ diterima, variabel leverage mempunyai nilai signifikansi sebesar 0,0001 nilai ini lebih kecil dari tingkat signifikansinya yaitu $0,05(\alpha=5 \%)$ sehingga dapat disimpulkan bahwa $\mathrm{H}_{0}$ ditolak dan $\mathrm{H}_{2}$ diterima yang dapat diartikan adanya pengaruh signifikan antara variabel leverage terhadap variabel nilai perusahaan secara parsial atau individual dan memiliki arah koefisien regresi positif sebesar 0,337275 terhadap nilai perusahaan oleh karena itu hipotesis kedua $\left(\mathrm{H}_{2}\right)$ diterima, ukuran perusahaan mempunyai nilai signifikansi sebesar 0,0878 nilai ini lebih besar dari tingkat signifikansinya yaitu $0,05(\alpha=5 \%)$ sehingga dapat 
disimpulkan bahwa $\mathrm{H}_{0}$ diterima dan $\mathrm{H}_{3}$ ditolak yang dapat diartikan tidak ada pengaruh yang signifikan antara variabel ukuran perusahaan terhadap nilai perusahaan secara parsial atau individual dan memiliki arah koefisien regresi positif sebesar 0,140058 terhadap nilai perusahaan oleh karena itu hipotesis ketiga $\left(\mathrm{H}_{3}\right)$ ditolak.

\section{DISKUSI}

Hasil pengujian statistik dengan uji parsial menunjukkan bahwa variabel profitabilitas dan leverage berpengaruh signifikan dan positif terhadap nilai perusahaan. Hasil pengujian statistik dengan uji parsial menunjukkan bahwa variabel ukuran perusahaan tidak berpengaruh secara signifikan terhadap nilai perusahaan.

\section{KESIMPULAN}

Berdasarkan hasil pengujian data dalam penelitian ini, maka dapat disimpulkan bahwa variabel profitabilitas dan leverage berpengaruh secara signifikan dan positif terhadap nilai perusahaan. Sedangkan hasil pengujian statistik dengan uji parsial menunjukkan bahwa variabel ukuran perusahaan tidak berpengaruh secara signifikan terhadap nilai perusahaan. Keterbatasan dari penelitian ini yaitu variabel yang digunakan dalam penelitian ini terbatas dikarenakan keterbatasan waktu penelitian. Disarankan untuk penelitian selanjutnya untuk memperpanjang periode penelitian, menambah variabelvariabel lain untuk diteliti. Selain itu, untuk perusahaan untuk memaksimalkan profitabilitas agar dapat memimgkatkan nilai perusahaan, mencapai struktur modal yang optimal, dan menjaga agar ukuran perusahaan semakin besar sehingga perusahaan lebih stabil.

\section{DAFTAR PUSTAKA}

Aggarwal, D., \& Padhan, P. C. (2017). Impact of Capital Structure on Firm Value: Evidence from Indian Hospitality Industry. Theoretical Economics Letters, 07(04), 982-1000. https://doi.org/10.4236/tel.2017.74067

Ayu, D. P., \& Suarjaya, A. A. G. (2017). Pengaruh Profitabilitas pada Nilai Perusahaan dengan Corporate Social Responsibility Sebagai Variabel Intervening. E-Journal Akuntansi Universitas Udayana, 22(2), 1557-1583.

Brigham, Eugene F. (2011). Financial Management Theory and Practice 13th. Printed in the US of America.

Brigham, Eugene F \& Joel F. Houston. (2014). Fundamentals of Financial Management, 14th Edition. Mason: South-Western Cengange Learning.

Harjito, D. Agus dan Martono, SU. (2014). Manajemen Keuangan. Edisi Kedua. Yogyakarta: Ekonisia.Ham

Hery. (2017). Kajian Riset Akuntansi. Jakarta: Grasindo.

Kalbuana, N., Juniar, U., \& Amrizal. (2017). Pengaruh Profitabilitas, Leverage, dan Size Terhadap Nilai Perusahaan Sektor Perbankan yang Terdaftar Di Bursa Efek Indonesia. Jurnal Akuntansi, (2460), 1-10.

Kasmir. (2014). Analisis Laporan Keuangan. Edisi Satu. Cetakan Ketujuh. Jakarta: PT Raja Grafindo Persada

Lubis, I. L., Sinaga, B. M., \& Sasongko, H. (2017). Pengaruh profitabilitas, sruktur modal, dan likuiditas terhadap nilai perusahaan. Aplibkasi Bisnis Dan Manajemen, 3(3), 458-465. Retrieved from http://journal.ipb.ac.id/index.php/jabm 
Lumoly, S., Murni, S., \& Untu, V. N. (2018). Pengaruh Likuiditas, Ukuran Perusahaan, dan Profitabilitas Terhadap Nilai Perusahaan. Jurnal EMBA, 6(3), 1108-1117.

Manoppo, H., \& Arie, F. V. (2016). Pengaruh Struktur Modal, Ukuran Perusahaan, dan Profitabilitas Terhadap Nilai Perusahaan Otomotif yang Terdaftar di Bursa Efek Indonesia Periode 2011-2014. Jurnal EMBA, 4(2), 485-497. https://doi.org/10.1002/eji.201444988.This

Oktrima, B. (2015). Pengaruh Profitabilitas, Likuiditas, dan Struktur Modal Terhadap Nilai Perusahaan, 1(2581), 98-107.

Rahmawati, A. D., Topowijono, \& Sulasmiyati, S. (2015). "Pengaruh Ukuran Perusahaan, Profitabilitas, Struktur Modal, dan Keputusan Investasi Terhadap Nilai Perusahaan". Jurnal Administrasi Bisnis, 23 (2)(2), 1-7. Retrieved from https://media.neliti.com/media/publications/85999-ID-pengaruh-ukuran-perusahaanprofitabilita.pdf

Riyanto, Bambang. (2001). Dasar-Dasar Pembelanjaan Perusahaan. Yogyakarta :BPFE

Rumondor, R., Mangantar, M., \& Sumarauw, J. S. B. (2015)." Pengaruh Struktur Modal, Ukuran Perusahaan dan Risiko Perusahaan terhadap Nilai Perusahaan pada Sub Sektor Plastik dan Pengemasan di BEI". Jurnal EMBA, 3(3), 159-169.

Salempang, L. E., Sondakh, J. J., \& Pusung, R. J. (2016). Pengaruh Return On Asset , Debt To Equity dan Pertumbuhan Penjualan terhadap Nilai Perusahaan pada Sektor Real Estate dan Property yang Terdaftar di BEI Tahun 2013-2014. Jurnal Berkala Ilmiah Efisiensi, 16(03), 813-824.

Sartono, Agus. (2010). Manajemen Keuangan Teori dan Aplikasi. Edisi Keempat.Yogyakarta: BPFE.

Syahyunan. (2015). Manajemen Keuangan - Perencanaan, Analisis dan Pengendalian Keuangan. Edisi Kedua. Medan: Penerbit USU Press.

Winarto, Jacinta. (2015). The Determinants of Manufacturer Firm Value in Indonesia Stock Exchange. International Journal of Information, Business and Management, 7(4), 323-350. https://doi.org/10.1016/j.ijinfomgt.2010.11.002

www.kontan.co.id 